\title{
PROFESSIONAL DEVELOPMENT AND TRAINING IN POST-SECONDARY EDUCATION: PARTICIPATION IN A SUBSIDIZED PROGRAM “EXPORT TRADE EXECUTIVE”
}

\author{
Afentouli Vasiliki, \\ Armakolas Stefanosi, \\ Kazana Athina \\ School of Pedagogical \& \\ Technological Education,
} Greece

\begin{abstract}
:
The economic conditions nowadays with the increased international competition, open borders, and easier money circulation in the market have created the need for additional production, while unemployment rates have been on the rise making adults required to enrich their knowledge attend training seminars in order to achieve a successful transition from the education stage to the labor market. These new market conditions have led to the promotion of professional development and training of the workforce, which will be achieved through vocational education (Valiente et al., 2020, Saar et al., 2013). At the same time, the need for more opportunities for personal and social development and employment has created lifelong learning in post-secondary education. Subsidized training programs are very often implemented, organized by large organizations, in order to provide additional knowledge to adult workers and the unemployed, regardless of age, level of knowledge, degree, and specialty. This study explores the motivation and the criteria of the participation in one of the Subsidized Unemployed Program with the title "Export Trade Executive". According to the results of the research, the driving force for the participation of adults in this kind of program is the professional development of the participants, the improvement of their professional skills, the adaptation to the new technological data, but also socialization through the program.
\end{abstract}

Keywords: professional development, lifelong learning, post-secondary education, motivations, seminar selection criteria

i Correspondence: email stefarmak@upatras.gr 


\section{Introduction}

The concept of "adult education" refers to an organized range of educational processes for adults, which helps to develop their skills, enrich their knowledge and improve their current professional status (Valiente et al., 2020, Heyes, 2013). Adult education and training seminars contribute to increasing employability (Barroso et al., 2019) but also to the professional development of those who participate in them.

The term professional development is a process that lasts a lifetime and refers to the evolutionary course of the individual in the workplace. Peters et al. (2019) report that the future of work can be improved by increasing the skills that individuals acquire from education and training institutions and then bring them to the workplace.

Vocational counseling and guidance include the development of a person's career. Uses methods and theories to help individuals make educational and professional decisions and manage career issues (Riverin - Simard, 2000). Typically, these theories attempt to predict professional behavior, determine the factors that influence it, and find ways to control behavior in order to help individuals achieve the expected outcomes of the educational process (Guskey \& Yoon, 2009). Psychological and non-psychological factors can positively or negatively affect the individual as to whether or not he will continue his professional choice. For personal developmental reasons, as adults face new situations and challenges on a daily basis, they feel the need to expand their cognitive interests (Lin \& Wank, 2015) and will create the desire to participate in training seminars, in order to acquire additional knowledge, but also more updated in his subject.

Adults usually participate consciously and with clear goals, sacrificing other priorities and interests, investing time, money, and effort (Tharp \& Gallimore, 1989), and choosing that specialty that will offer them specific knowledge and skills that can be applied directly to practice (Lin \& Wank, 2015). This is because, due to their age and experiences, they already have formed attitudes and perceptions, therefore they know where to focus (Fairchild, 2003). They also know that the programs in which they participate, aim at the development of skills, therefore, the main motivation for participation in training seminars is the desire and the need of the individual to expand and develop his knowledge in the field of his work, but also to harmonize with new technological data and practices. They often ask for courses not to be standardized and prefabricated, but to meet specific needs and requirements (McCallum, 2012). Therefore, the goal of the trainee is to continuously improve. According to Lin \& Wank (2015), professional development and job requirements are factors that push adults into learning. In fact, there are times when adult trainees are encouraged by their own employers to participate with motivation to acquire more skills and upgrade their job roles (Mohammed et al. , 2020, Kumar, 2012). So, some trainees participate so that they can improve and develop their professional skills, develop professionally, and others just to integrate into a social or political group, social event (Kasworm, 2003) to socialize (Gray et al., 2008, Jasper, 2011). Finally, there are some adults who believe that a degree will give them prestige and a higher social class (Kasworm, 2003). 


\section{Adult Education and Lifelong Learning in Post-Secondary Education}

Adult education is part of lifelong learning and is a systematic and well-organized learning process for adult trainees. The goal is to increase employability and economic growth (Barroso et al., 2019, Kotthof et al., 2017). Post-secondary education can be characterized as a means of transition of adults (Barroso et al., 2019) from secondary to tertiary education. Knowledge and skills are provided that help the trainee to develop both personally and professionally. The programs accept students who have already completed secondary education and are interested in expanding their knowledge and preparing them for immediate entry into the labor market.

According to psychological theories, interests, personality, and values are factors that influence the choice of profession and specialization. In contrast, in nonpsychological theories, individuals choose a professional career influenced by external factors, such as luck, financial gain, and the socio-cultural environment from which they are enclosed (Siddiky \& Akter, 2021; Kazi \& Akhlaq, 2017; Saleem et al., 2014). In addition, professional development can be achieved through the participation of adults in educational and training programs, gaining additional knowledge and skills, which will then be used in the workplace (Peters, et al., 2019).

In the Greek educational system, post-secondary education is mainly related to Public I.E.K. (Institutes of Vocational Training) of Youth and Lifelong Learning Foundation - I.NE.DI.VI.M., Private I.E.K. and the I.E.K. of O.A.E.D. in which there is a wide variety of specialties, the I.E.K. of the Ministry of Tourism, in which the specialties are related to the tourism sector, and in I.E.K. of EKAB, in the Public Institutes of Vocational Training of Special Education (DIEK of Special Education), in the Vocational Training Centers (KEK) and in the Lifelong Learning Centers (KDVM), which are private, undertake subsidized training programs, and are aimed at either employees or the unemployed, depending on the nature of the program.

\subsection{Motivation in lifelong learning}

Bomia et al. (1997) identify motivation as a student's willingness, need, desire, and compulsion to participate in and succeed in the learning process. Intrinsic motivation is the activity performed only for personal satisfaction without any external influence (Rayn $\&$ Deci, 2000, Gopalan et al., 2017). The key factors that drive intrinsic motivation are a challenge, curiosity, control, and imagination. Education, especially for adults, requires willingness and a positive attitude in order to maintain motivation. In addition, PerezLopez \& Contero (2013) estimate that there is a significant positive correlation between intrinsic motivation and academic achievement. In contrast, external motivation reflects external activities such as reward, coercion, and punishment (Tohidi \& Jabbari, 2012). A person has exogenous motivations when he receives any reward or works under pressure or coercion. There is the case that motivation is initially cultivated by exogenous factors, but then through the deeper learning process is transformed into an endogenous motivation (Tohidi \& Jabbari, 2012). Intrinsic motivation is self-motivation for learning, 
while external motivation is the goal for the trainee to continue learning (Li \& Lynch, 2016).

The theory of self-disposition is another approach to human motivation and is determined by both endogenous and exogenous motivations (Ross et al., 2016). Man's innate tendencies for growth and mental needs are the basis of this approach, which argues that it is these factors that lead adults to adopt specific positive behaviors with the aim of identifying the factors that strengthen their innate potential for personal growth, prosperity, and social and organizational integration.

The individual must realize that in order to receive an attractive reward he must act in a specific way, which will lead to the goal. Conversely, if he believes that his performance or remuneration is independent of his effort and performance, then there will be no interest in making more effort (Gopalan et al., 2017).

An educational training process can become effective once the program is properly designed. Appropriate planning initially involves identifying the training needs of the target group of the program (Okolie et al., 2020).

\section{Methodology}

The research was conducted on long-term unemployed people aged 21-60, who have completed at least higher education, and attended the subsidized training seminar "Export Trade Executive". The duration of the program was four months, and the seminar was conducted by the method of synchronous distance learning. Upon completion of the synchronous theoretical part has followed a mandatory internship of 110 hours in an export company.

During the program, five individual sessions of career guidance counseling were provided, for each beneficiary. The implementation time of the program was February 2021 until May 2021, in the midst of the covid-19 pandemic. After the completion of the internship, the trainees took certification exams and received a certificate of participation in the program and the amount of the grant, worth 2,500 euros.

The questionnaires were distributed online, during the synchronous training, and the participants followed relevant instructions on how to complete them. The research was conducted on a random sample of 64 people.

Regarding the way of designing the questionnaire, was made an effort to make a short questionnaire, to have a logical sequence between the questions, to make a grouping of the questions based on the research objectives, the questions to be formulated with a clear and understandable way of answering them (Brace, 2018) and to allow further statistical processing of data (Lagoumitzis et al., 2015).

On the basis of the above-mentioned research and theoretical data, the main axes of the questionnaire of the interviews were created. More specifically, the questionnaire contained 27 questions that were divided into three main axes. The questionnaire was based on similar research by Kim et al. (2020), Lee et al. (2013), Theodoridis (2011), Raghavan et al. (2008), Kortesoja (2006). 
The Likert scale was used for the analysis of the questionnaire data, which consists of five elements (Strongly Disagree - Strongly Agree) (Brace, 2018). These five elements are used as a quantitative measure for the analysis of questions (Boone et al., 2012).

The main purpose of this survey is to investigate the characteristics of the people participating in the subsidized program "Export Trade Executive", the reasons and motivations for their participation, the factors that pushed them to choose the specific program, and how they believe that this seminar will help them in their professional development.

Based on the above research objectives, we try to answer the following research questions.

Research Question 1: What are the reasons for the participation of the unemployed trainees in the subsidized educational program "Export Trade Executive"?

Research Question 2: What factors influenced the trainees to choose the specific seminar according to their age?

Research Question 3: How much do the trainees appreciate that the seminar will help them in vocational rehabilitation?

The sample included sixty-four adults [18 men and 46 women], of whom:

- 7 are 21 to 30 years old,

- 22 to 31 to 40 years old,

- 2041 to 50 years old, and

- 15 people aged 51 and over $(23.4 \%)$.

From the sample, 78.1\% hold a University Degree or Higher Education Degree (50 people), $18.8 \%$ hold a master's degree (12 people), and only $3.1 \%$ hold a doctorate (2 people). Regarding the subject of their studies, the largest percentage of trainees has a subject of studies related to that of the seminar. Specifically, 52\% (33 people) studied economics, $20 \%$ (13 people) studied positive sciences and 28\% (18 people) studied theoretical-social sciences. Finally, regarding the overall work experience of the trainees: the largest percentage of participants have a total of 6 to 10 years of work experience $(29.7 \%)$, follows the percentage of the trainees $28.1 \%$, with those who have from 0 to 5 years work experience, 10 to 15 years of service have a percentage of $20.3 \%$, they with work experience of 20 years and over with a percentage of $14.1 \%$ and finally those who have 15 to 20 years of work experience with a percentage of $7.8 \%$.

\section{Results and Discussion}

The first research question dealt with the reasons for the participation of the unemployed trainees in the subsidized educational program "Export Trade Executive" carried out by the S.E.V.E. (Exporters Association of Northern Greece).

According to the results of the analysis, the reasons for the participation are distinguished in personal, economic, and social.

The answer to the first research question is reflected in the graph below, where $96.9 \%$ of the trainees said that the program will help them to develop themselves and 
$85.9 \%$ said that the financial benefit, they will receive from the participation is a very important reason for participation. Only $57.8 \%$ of the participants believe that they have many chances to recover professionally after this certification, 59\% of the trainees declare as a reason for participating in the program the acquaintance with new people, and $53.2 \%$ the integration into a group. The factors, utilization of free time, and were the only openactive subsidized program, occupy the lowest percentages with $46.9 \%$ and $35.9 \%$ respectively.

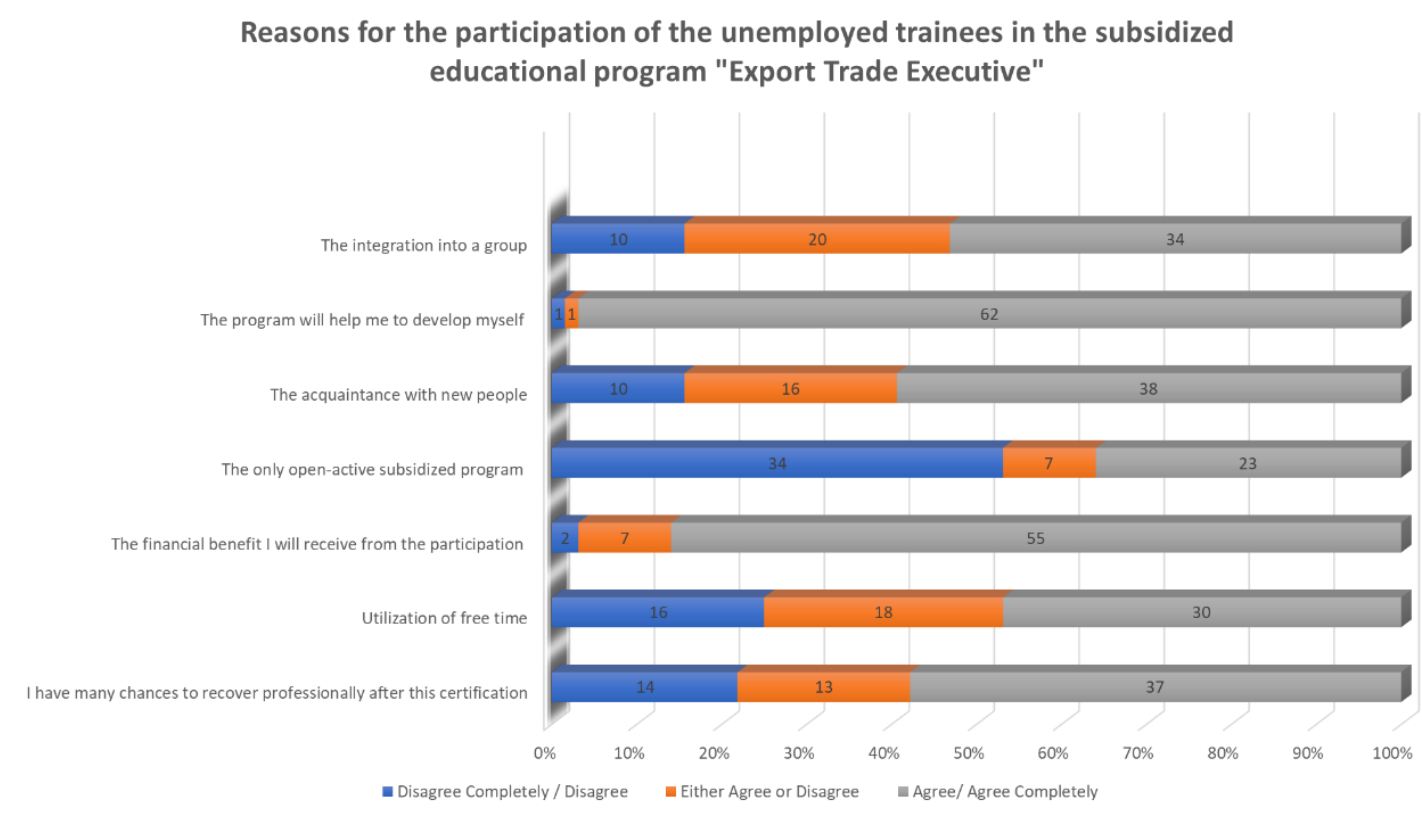

Figure 1: Reasons for the participation of the unemployed trainees in the subsidized educational program "Export Trade Executive"

The second research question dealt with the factors that influenced the trainees to choose the specific program according to their age. The participants in the program were categorized into four age groups 21 to 30 years old, 31 to 40 years old, 41 to 50 years old, 51 and over. The motivations given to the trainees according to the answers (Table 1) were "I was interested in the seminar", " I will gain additional professional prestige with the certification ", " The possibility of being offered a job in the company where I will do the internship ", "Distance training "," I will acquire general knowledge "," Financial benefits "," I will escape from the boredom and frustration of everyday life due to pandemic covid-19".

As the results shows, financial earnings, as well as the acquisition of general knowledge, are the main motivations for choosing the program, as in all age groups the majority of the participants states that it has been affected. 
Table 1: Factors for selecting to participate in the subsidized educational program "Export Trade Executive" according to group ages

\begin{tabular}{|l|c|c|c|c|}
\hline \multirow{2}{*}{ Factors } & \multicolumn{3}{|c|}{ Age Group } \\
\cline { 2 - 5 } & $\mathbf{2 1 - 3 0}$ & $\mathbf{3 1 - 4 0}$ & $\mathbf{4 1 - 5 0}$ & $\mathbf{5 1 +}$ \\
\hline I was interested in the seminar & $71.4 \%$ & $40.9 \%$ & $90 \%$ & $93.3 \%$ \\
\hline $\begin{array}{l}\text { I will gain additional professional prestige } \\
\text { with the certification }\end{array}$ & $57.1 \%$ & $45.5 \%$ & $60 \%$ & $40 \%$ \\
\hline $\begin{array}{l}\text { The possibility of being offered a job in the } \\
\text { company where I will do the internship }\end{array}$ & $58 \%$ & $82 \%$ & $55 \%$ & $46.7 \%$ \\
\hline Distance Learning & $42.9 \%$ & $59.1 \%$ & $60 \%$ & $73.3 \%$ \\
\hline I will acquire general knowledge & $85.7 \%$ & $90.9 \%$ & $90 \%$ & $86.7 \%$ \\
\hline Financial benefits & $85.7 \%$ & $90.9 \%$ & $95 \%$ & $93.3 \%$ \\
\hline $\begin{array}{l}\text { I will escape from the boredom and frustration } \\
\text { of everyday life due to pandemic covid-19 }\end{array}$ & $85.7 \%$ & $72.7 \%$ & $70 \%$ & $53.3 \%$ \\
\hline
\end{tabular}

\section{a. Age group 21 to 30 years}

The factors that influenced the age group of 21 to 30 years to choose this seminar were mainly the financial benefits that they will earn with a percentage of $85.7 \%$, the object of the seminar, which attracted the interest of $71.4 \%$ of the participants, and the general knowledge they acquire at a rate of $85.7 \%$. Other factors were psychological, as $85.71 \%$ of the participants stated that they would escape from the boredom and frustration of everyday life due to Covid 19, and then 57.1\% of them estimated that with the certification they would gain additional professional prestige, $58 \%$ estimate that there is a possibility that they will provide him with a job in the company that will do the internship.

\section{b. Age group 31 to 40 years}

The factors that influenced the age group of 31 to 40 years to choose this seminar were mainly the financial benefits that they will earn at a rate of $90.9 \%$, the object of the seminar, which attracted the interest of $40.9 \%$ of the participants, and the general knowledge they acquire with a percentage of $90.9 \%$. Other factors were psychological, as $72.7 \%$ of the participants stated that they would escape the boredom and frustration of everyday life due to Covid 19, and then, $45.5 \%$ estimated that with the certification they would gain additional professional prestige, $82 \%$ estimate that there is a possibility that they will provide him with a job in the company that will do the internship.

\section{c. Age group 41 to 50 years}

The factors that influenced the age group of 41 to 50 years to choose this seminar were mainly the financial benefits that will be obtained at a rate of $95 \%$, the object of the seminar, which attracted the interest of $90 \%$ of the participants, and the general knowledge that acquire at a rate of $90 \%$. Other factors were psychological, as $70 \%$ stated that they would escape the boredom and frustration of everyday life due to Covid 19, and then, $60 \%$ estimated that with the certification they would gain additional professional prestige, $55 \%$ estimated that there is a possibility to provides them with 
work in the company that will do the internship. Finally, it is worth noting that an important factor in participation with a percentage of $60 \%$ was that the program occurred with Distance Learning.

\section{d. Age Group 51 years and older}

The factors that influenced the age group of 51 years and over to choose this seminar were mainly the financial benefits that they will gain at a rate of $93.3 \%$, the object of the seminar, which attracted the interest of $93.3 \%$ of the participants, and the general knowledge they acquire with a percentage of $86.7 \%$. Other factors were psychological, as $53.3 \%$ said they would escape the boredom and frustration of everyday life due to Covid 19 , and then $40 \%$ estimated that with the certification they would gain additional professional prestige, $46.7 \%$ estimate that there is a possibility that they will provide him with a job in the company that will do the internship. Finally, it is worth noting that an important factor in participation with a percentage of $73.3 \%$ was that the program occurred with Distance Learning.

Finally, the third research question concerned the future development prospects and the vocational rehabilitation of the trainees participating in the seminar.

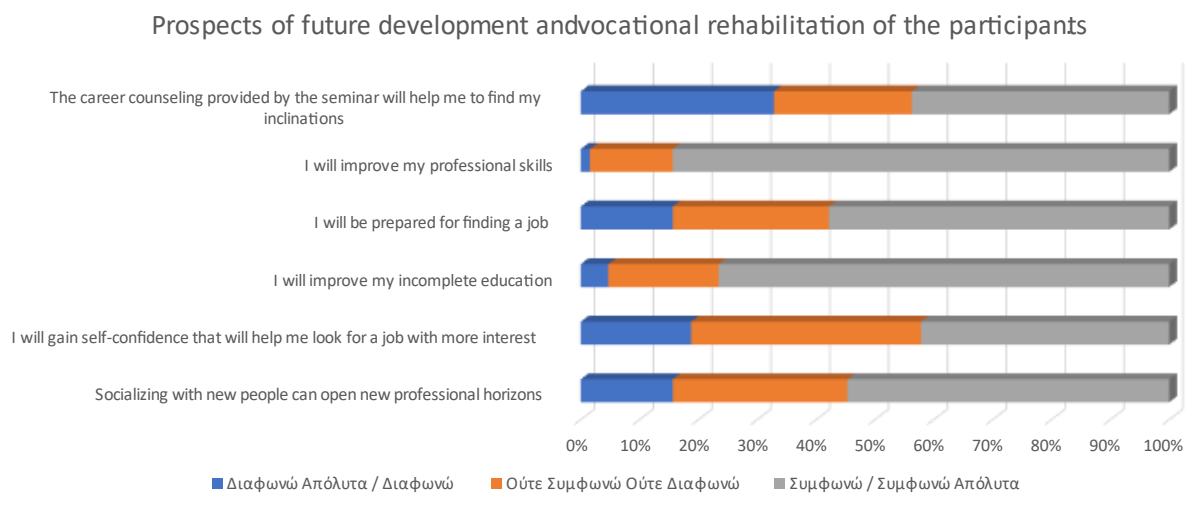

Figure 2: Prospects of future development and vocational rehabilitation of the participants

The results showed that the desirable development prospects that probably will help them evolve in the future and open new professional horizons, according to their answers are the following: improving professional skills, enhancing incomplete education, preparing for job search, and socializing with other people.

When the participants have been asked whether the career counseling provided by the seminar will help them to find their inclinations, $32.9 \%$ say that the career counseling provided by the seminar will not help to find the inclinations.

Regarding the improvement of professional skills, the participants in the program in the largest percentage ( $84.4 \%$ ) estimate that it will help them professionally to a small 
degree or even a very large degree, $14.1 \%$ consider it indifferent whether the no will improve, and only $1.5 \%$ estimates that they will not gain anything from the seminar.

In relation to the preparation for finding a job, we observe that the subjects of the research present a "small" degree $(15.6 \%)$ of the influence of the factor. A percentage of $26.6 \%$ of the sample appears indifferent to the possibility of better preparation for finding work through the program.

Regarding whether the seminar will help the trainees to improve their incomplete education, $3.1 \%$ estimate that it will not help them at all, $1.6 \%$ that it will simply not help them and, $18.8 \%$ state that they do not care whether or not it will help. It is worth noting here that almost all respondents who gave this answer were over 51 years old and with many years of experience. Also, $54.7 \%$ of the participants believe that they will improve their knowledge to a small degree, while $21.9 \%$ that they will improve it to a great extent. Regarding whether the seminar will help the trainees to gain self-confidence that will help them look for a job with more interest, $1.6 \%$ estimate that it will not help them at all, $17.2 \%$ that it will simply not help them and $39.1 \%$ say they do not care whether it will be helped or not. Finally, $29.7 \%$ of the participants believe that they will gain a small degree of self-confidence, while $12.5 \%$ that they will improve it to a great extent.

Finally, as to whether participation in the seminar will help trainees to develop their social interactions and open new professional horizons, $15.6 \%$ believe that it will simply not help them, while $29.7 \%$ say they do not care if will help or not. Finally, $40.6 \%$ of the participants believe that socializing with new people can open new professional horizons to a small extent, while only $14.1 \%$ that it will be affected to a great extent.

\section{Conclusions}

The aim of this research was to study the motivation and the characteristics of the people participating in the subsidized program "Export Trade Executive", the factors that pushed them to choose the specific program, and how they believe that this seminar will help them in their professional development.

The research showed that the participants are people of all ages, mainly graduates of Universities or Technical Colleges, and some of them hold a Master of Science or a Doctorate. Also, they have several years of the previous service. The reasons for participating in the program are mainly for vocational rehabilitation, to use their free time, for the financial benefits they will earn, to meet new people and socialize, to develop themselves, and integrate into a team. It is worth noting that before choosing an educational program, the participants also searched for any other open programs that may be of interest to them and help them improve their knowledge.

The motivations of the trainees are mainly the object of the program which they consider very interesting, and they estimate that with the certification they will gain additional prestige. In addition, they consider that there is a good chance that after the internship, they will continue to work for the company where they will carry out their internship. Another key motivation is that the training is done remotely, which serves 
both financially and temporally. Finally, the intrinsic motivation gives them the hope that through the program they will escape from the routine, boredom, and frustration of everyday life due to covid-19.

The third research question was in terms of whether the participants estimate that they will be helped by their participation in the program, or they consider that they will greatly improve their professional skills as well as their lack of previous knowledge. In addition, we investigate if the program will help them first of all to gain confidence, and secondly if through their social interaction with new people new horizons will be opened for them.

However, they state that the career counseling provided to them during the program should have helped them more in order to find their inclinations and interests. In conclusion, this research could be expanded and used as a powerful tool to help connect the labor market with specialized and well-qualified unemployed persons.

\subsection{Limitations of the study - Suggestions for Future Research}

A limitation of this study is that the program targeted 220 unemployed graduates and the researchers had access to only 64 participants of the program. In order for all trainees to be able to participate, a special permit had to be obtained from the implementation body (SEVE) and then this permission had to be sent to all the Vocational Training Centers who had undertaken to implement this program.

The present research highlights the potential usefulness of the participation of individuals in subsidized programs for the unemployed. Also, will give impetus to new research approaches that will investigate the reasons for participating in similar seminars according to the age of the participants or will attempt a further analysis of whether the trainees believe that this kind of seminars will help them to improve their position in labor market using their basic degree. Future research should be undertaken to explore how the selection criteria of educational programs and the preferred learning methods will affect the design and implementation of the subsidized employee programs.

\section{Conflict of Interest Statement}

The authors declare no conflicts of interests.

\section{About the Authors}

Vasiliki Afentouli holds a BSc in Economics \& Social Science and a MSc in Finance and Accounting from the University of Macedonia. She has worked as a certified financial accountant in big firms for about twelve years, but the last five years she is a tutor at Private and State Institutes of Adults Professional Training. In 2017 she graduated from the higher school of Pedagogical and Technological Education (ASPETE). She is certified Adult Group Educator from INEDIVIM (Youth and Lifelong Learning Education), and certified Professional Career Counselor from PESYP (Specialization Program in Counseling and Orientation). 
Stefanos Armakolas has been a member of the instructional Laboratory Personnel at the Department of Education and Social work of the University of Patras. He holds a B.Sc. from Dept. of Technological Applications of Technological Educational Institute of Piraeus, and Master in Education from Dept. of Humanities of Hellenic Open University. His teaching experience includes teacher education and training on these topics: Teaching Practical Exercises, Educational Technology, Pedagogical Applications with New Technologies. He holds a PhD at the Department of Primary Education of University of Patras.

Athina Kazana is an experienced Agronomist and she has two MSc. The first one is in "Geological and Atmospheric Environment for infrastructure projects" and the second one in "Entrepreneurship \& Consulting in Rural Development". Also, in 2019 she received her Certificate in pedagogical training from the School of Pedagogical and Technological Education (ASPETE). She has attended various seminars including Special Education and Adult Learning and she is a certified Adult Educator from EOPPEP (National Organisation for the Certification of Qualifications \& Vocational Guidance). Her teaching experience includes teacher education and training on these topics: Teacher in Second Chance Schools and Educator in seminars for farmers from ELGO DEMETEROrganization [Hellinic Ministry of Rural Development and Food, ATHENS (Greece)].

\section{References}

Barroso-Hurtado, D., \& Chan, R., 2019. Why enroll in a lifelong learning programme? A comparative study of Austrian and Spanish young adults. Social Inclusion, 7(3), 110-121.

Bomia, L., Beluzo, L., Demeester, D., Elander, K., Johnson, M., \& Sheldon, B., 1997. The Impact of Teaching Strategies on Intrinsic Motivation. Retrieved from https://files.eric.ed.gov/fulltext/ED418925.pdf

Boone, H. N., \& Boone, D. A., 2012. Analyzing likert data. Journal of extension, 50(2), 1-5.

Brace, I., 2018. Questionnaire design: How to plan, structure and write survey material for effective market research. Kogan Page Publishers.

Fairchild, E., 2003. Multiple Roles of Adult Learners, https://doi.org/10.1002/ss.84

Gray, P. K., Golding, L., \& Collins, C., 2008. A Practical Guide to Meeting CPD Needs. Continuing Professional Development for Clinical Psychologists: A Practical Handbook, 47.

Gopalan, V., Bakar, J. A. A., Zulkifli, A. N., Alwi, A., \& Mat, R. C., 2017. A review of the motivation theories in learning. In AIP Conference Proceedings (Vol. 1891, No. 1, p. 020043). AIP Publishing LLC.

Guskey, T. R., \& Yoon, K. S., 2009. What works in professional development? Phi delta kappan, 90(7), 495-500. 
Heyes, J., 2013. Vocational training, employability and the post-2008 jobs crisis: Responses in the European Union. Economic and industrial democracy, 34(2), 291311.

Jasper, M., 2011. Professional development, reflection and decision-making for nurses (Vol. 17). John Wiley \& Sons.

Kasworm, C. E., 2003. Setting the stage: Adults in higher education. New directions for student services, 2003(102), 3-10.

Kazi A. S., \& Akhlaq, A. 2017. Factors affecting students career choice, Journal of Research and Reflections in Education, vol.11, no.2, pp.186-196. (12) (PDF). The students' career choice and job preparedness strategies: A social environmental perspective. Available from: https://www.researchgate.net/publication/351270199 The students' career choic e and job preparedness strategies A social environmental perspective [accessed Oct 13 2021].

Kim, J., Geesa, R. L., \& McDonald, K., 2020. School Principals' and Counselors' Focus on College-Going: The Impact of School Leader Expectations and Primary Counseling Goals on Postsecondary Education. Journal of College Access, 5(2), 3251.

Kortesoja, S., 2006. Factors Influencing Nontraditional Age Student Participation in Postsecondary Education: How Do Student Motivations and Characteristics Relate to Adult Participation in Credential Programs? Retrieved from: https://files.eric.ed.gov/fulltext/ED493827.pdf

Kotthoff, H. G., Carillo Gáfaro, J. F., Bittlingmayer, U. H., Boutiuc-Kaiser, A., Parreira do Amaral, M., \& Rinne, R., 2017. Work Package 3 International Report: LLL Policies and Inclusion in Education and Work. YOUNG_ADULLLT Working Papers. Freiburg, Germany: University of Education Freiburg.

Kumar, A., 2012. Philosophical background of adult and lifelong learning. Erişim, 24, 2017.

Lagoumitzis, G., Vlachopoulos, G., \& Koutsogiannis, K., 2015. Data Collection Methods. Retrieved from https://repository.kallipos.gr/handle/11419/5360

Lee, P. L., \& Pang, V., 2013. Motivational orientations in adult learning: comparing a public and private university. Journal of Institutional Research South East Asia, 11(2).

Li, T., \& Lynch, R., 2016. The relationship between motivation for learning and academic achievement among basic and advanced level students studying Chinese as a foreign language in years 3 to 6 at Ascot International School in Bangkok, Thailand. Scholar: Human Sciences, 8(1), 1-1.

Lin, X., \& Wang, C. H., 2015. Exploring Predictive Factors Influencing Returning International and American Adult Learners' Motivational Orientations. International Research in Higher Education, 1(1), 1-8.

McCallum, A., 2012. Creativity and Learning in Secondary English: Teaching for a Creative Classroom, London: Routledge. ISBN: 978-0- 415-62070-3 (pbk); 159pp. 
Mohammed, S., \& Kinyo, L., 2020. Constructivist theory as a foundation for the utilization of digital technology in the lifelong learning process. Turkish Online Journal of Distance Education, 21(4), 90-109.

Okolie, U. C., Nwajiuba, C. A., Binuomote, M. O., Ehiobuche, C., Igu, N. C. N., \& Ajoke, O. S., 2020. Career training with mentoring programs in higher education: facilitating career development and employability of graduates. Education+Training.

Retrieved

from:

https://www.researchgate.net/profile/Ugochukwu-Okolie-

2/publication/340165436 Career training with mentoring programs in higher education Facilitating career development and employability of graduates/li nks/5f0d7314299bf15bd70b1922/Career-training-with-mentoring-programs-inhigher-education-Facilitating-career-development-and-employability-ofgraduates.pdf

Pérez-López, D., \& Contero, M., 2013. Delivering educational multimedia contents through an augmented reality application: A case study on its impact on knowledge acquisition and retention. Turkish Online Journal of Educational Technology-TOJET, 12(4), 19-28.

Peters, M. A., Jandrić, P., \& Hayes, S., 2019. The curious promise of educationalising technological unemployment: What can place of learning really do about the future of work? Educational Philosophy and Theory, 51(3), 242-254.

Raghavan, S., \& Kumar, P. R., 2008. The need for participation in open and distance education: The Open University Malaysia experience. Turkish Online Journal of Distance Education, 9(4), 77-89.

Riverin-Simard, D., 2000. Career development in a changing context of the second part of working life. The future of career, 115-129.

Ross, M., Perkins, H., \& Bodey, K., 2016. Academic motivation and information literacy self-efficacy: The importance of a simple desire to know. Library $\mathcal{E}$ information science research, 38(1), 2-9.

Ryan, R. M., \& Deci, E. L., 2000. Self-determination theory and the facilitation of intrinsic motivation, social development, and well-being. American psychologist, 55(1), 68.

Saar, E., Ure, O. B., \& Holdford, J., 2013. Lifelong Learning in Europe: National Patterns and Challenges Northampton, MA, USA/Cheltenham, UK: Edward Elgar Publishing, Reviewed by: Howard A. Doughty An opening word about the publisher: Edward Elgar Publishing is not for the.

Saleem, N., Hanan, M.A., Saleem, I., and Shamshad, R.M., 2014. "Career selection: role of parent's profession, mass media and personal choice," Bulletin of Education and Research, vol. 36, no. 2, pp. 25-37, 2014. (12) (PDF). The students' career choice and job preparedness strategies: A social environmental perspective. Available from: https://www.researchgate.net/publication/351270199 The students' career choic e and job preparedness strategies A social environmental perspective [accessed Oct 13 2021]. 
Siddiky, R., \& Akter, S., 2021. The students' career choice and job preparedness strategies: A social environmental perspective, International Journal of Evaluation and Research in Education (IJERE) 10(2):421-431, DOI: 10.11591/ijere.v10i2.21086

Tharp, R., \& Gallimore, R., 1989. Rousing Minds to Life: Teaching, Learning, and Schooling in Social Context. Cambridge: Cambridge University Press. doi:10.1017/CBO9781139173698

Tohidi, H., \& Jabbari, M. M., (2012). The effects of motivation in education. Procedia-Social and Behavioral Sciences, 31, 820-824.

Valiente, O., Capsada-Munsech, Q., \& G. de Otero, J. P. (2020). Educationalisation of youth unemployment through lifelong learning policies in Europe. European Educational Research Journal, 19(6), 525-543. 
Creative Commons licensing terms

Authors will retain the copyright of their published articles agreeing that a Creative Commons Attribution 4.0 International License (CC BY 4.0) terms will be applied to their work. Under the terms of this license, no permission is required from the author(s) or publisher for members of the community to copy, distribute, transmit or adapt the article content, providing a proper, prominent and unambiguous attribution to the authors in a manner that makes clear that the materials are being reused under permission of a Creative Commons License. Views, opinions and conclusions expressed in this research article are views, opinions and conclusions of the author(s). Open Access Publishing Group and European Journal of Open Education and E-learning Studies shall not be responsible or answerable for any loss, damage or liability caused in relation to/arising out of conflict of interests, copyright violations and inappropriate or inaccurate use of any kind content related or integrated on the research work. All the published works are meeting the Open Access Publishing requirements and can be freely accessed, shared, modified, distributed and used in educational, commercial and non-commercial purposes under a Creative Commons Attribution 4.0 International License (CC BY 4.0). 